\title{
Research on the Training Mode of Digital Art Specialty Integrating Innovation and Entrepreneurship Education
}

\author{
Wenbin $\mathrm{Ge}^{1 *}$, Lin $\mathrm{Gao}^{2}$ \\ ${ }^{1}$ School of Art and Design, Liaoning Shihua University, Fushun, Liaoning; 113001, China \\ ${ }^{2}$ School of Art and Design, Liaoning Shihua University, Fushun, Liaoning; 113001, China
}

\begin{abstract}
As a new way of employment which can improve the national innovation ability, innovation and entrepreneurship is a necessary measure to be taken in a certain stage of socio-economic development, and a necessary means to realize socio-economic development. Facing the regional culture of different countries, dynamic simulation images can cross the barriers of text and language to achieve the ideal effect of the convenient communication and the efficient delivery. Digital art is an omni-directional visual representation for the purpose of the principle of expression, information transmission, commercial profit and many other needs. Encouraging students to start their own businesses through innovation and entrepreneurship education meets the need of contemporary college students, can effectively improve the school employment rate, can solve the problems faced by the current development of digital art industry, and furthermore, it is a new way out and ultimate goal for the development of digital art education.
\end{abstract}

\section{Introduction}

At present, College graduates majoring in digital art are difficult to enter the enterprise to directly participate in the work, and it becomes the norm that college graduates become unemployed upon graduation. The employment rate of colleges and universities is low, but the digital art industry is in urgent need of digital art talents who can "work ". The development of Chinese digital art industry is stagnant, and most of them imitate the style of the United States, Japan and South Korea, without their own characteristics. Chinese digital art industry urgently needs a batch of innovative talents to drive Chinese digital art to create a new glory.

With the changes in the domestic new media environment in recent years, digital art is no longer limited to a single digital art film, but is integrated into various walks of life in people's daily life through diversified forms of expression. The cross-industry application and functional changes of digital art have brought more convenient and more real feelings to our lives. Digital art has indeed become a new way of expression extending to all areas of society.

In the industrial machinery manufacturing industry, functional digital art has become one of the important auxiliary means of mechanical research and design. The combination of virtual reality technology and digital art to simulate mechanical parts and structure disassembly has become a model of application in the industrial field. Taking The Interactive Design of Oil Drilling and Production Engineering System in Liaoning Shihua University as an example (figure 1), digital art combines microscopic incomprehensible knowledge with dynamic models, and dynamically simulates the whole technological process of oil drilling and production with the method of different conversion lens, which can effectively improve the transformation efficiency of knowledge in this professional field. Therefore, in addition to the fact that digital art can fully and truly show the designer's design concept, its cross-industry application is indeed a powerful assistant in the field of industrial manufacturing, and this way of digital art expression is also the innovation point of digital art. It is an inevitable choice for the development of the professional training model by integrating innovation and entrepreneurship into the training of digital arts.

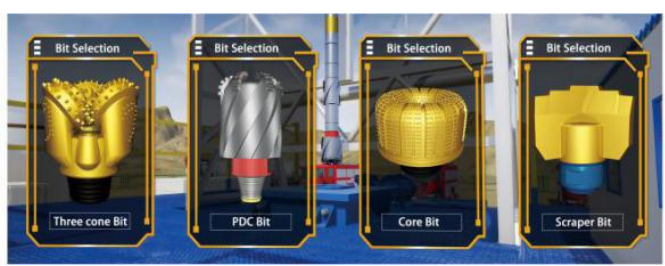

Figure 1. The interactive control interface of bit selection in oil drilling and production engineering system.

\section{It is an inevitable choice for the new era to integrate innovation and entrepreneurship education into the training mode of digital art specialty}

The new era requires that digital art professionals not only have digital art production ability, but also have digital art creation ability (figure 2). The cultivation of 
innovative digital art professionals is a critical task for colleges and universities and a fundamental way to solve the problem of the low employment rate. At the same time, it can effectively solve social and economic problems by innovation and entrepreneurship.

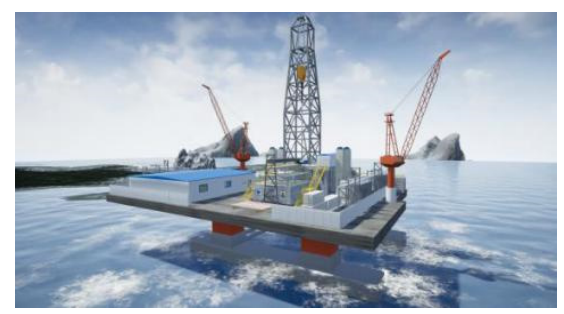

Figure 2. The platform of offshore oil drilling operation.

\subsection{Innovation and entrepreneurship is the need for contemporary college students to achieve self-development}

The employment situation of digital art graduate is severe, and there is not enough demand for the jobs available to meet the demand of college graduates, so it is necessary to encourage digital art graduates to innovate and start businesses. Innovation and entrepreneurship provides a new direction for solving the employment problem of college students. Innovation and entrepreneurship education can stimulate personal curiosity and one's thirst for knowledge, cultivate digital art talents with entrepreneurial spirit, and make them adapt to the fierce social competition. More and more attention has been payed to the construction of digital art professional education mode integrating innovation and entrepreneurship.

\subsection{Innovation and entrepreneurship education is an inevitable requirement of digital art professional education}

Improving the quality of running a school is a key step to realize the development of digital art professional education. In order to achieve the goal of cultivating talents conforming to the social development and meet the industry standards, it is necessary to carry out innovation and entrepreneurship education. Entrepreneurship education is a kind of education that enables students to have rich knowledge of innovation and entrepreneurship and strong practical ability through cultivation. Practice is a necessary ability for college students to innovate and start a business. The essence of entrepreneurship is innovation, and the improvement of the talent training model has a pivotal role in digital art professional education interspersed with innovation and entrepreneurial ideas.

\subsection{Innovation and entrepreneurship of college students is the breakthrough of socio-economic development}

Innovation and entrepreneurship is a necessary measure to be taken in a certain stage of socio-economic development, and it is also an inevitable means to realize socio-economic development. Innovative talents and innovative enterprises become the new pillars of socio-economic development. In such a big environment, innovation and entrepreneurship education should be carried out in colleges and universities, encouraging college students to start a business, which lays a foundation for improving the employment competitiveness of college students. Through innovation and entrepreneurship of college students improving the ability of social innovation, socio-economic problems can be solved.

\section{The origin of innovation and entrepreneurship education is in perfect accord with the origin of digital art professional education}

From the origin of innovation and entrepreneurship education and digital art professional education, there is a perfect convergence point between them. Digital art creation itself is an innovation emphasizing creativity as its root. Digital art education is a process of guiding students to create ideas through a certain training mode to complete digital art creation. The concept of innovation is embodied in every link of digital art creation. Entrepreneurship and innovation have a natural connection, entrepreneurship itself is a kind of innovation, and innovation and entrepreneurship is based on creativity.

\subsection{The Origin of Innovation and Entrepreneurship Education}

Cultivating students' innovative knowledge, entrepreneurial quality and entrepreneurial ability is the goal of innovation and entrepreneurship education, and the education of cultivating the spirit of innovation and entrepreneurship and professional quality is the focus of the educational activity. Based on creativity and practice, innovation and entrepreneurship education pursues the ideological transformation and encourages creativity with the characteristics of creativity and practicality. Innovation is a complex process of thinking and practicing, which refers to the human activities that produce new things and new ideas, which do not exist at present, through certain thinking and practicing. Entrepreneurship and innovation have a natural connection, and entrepreneurship itself is an innovation.

\subsection{The Origin of Digital art Education}

Digital art is a creative activity from scratch, and its core is creativity. Creativity and innovation based on each other, and they are indispensable. Art education is the foundation of digital art education, and the cultivation of students' creativity and ingenuity runs through the whole training system and process of digital art education. The whole training process is based on digital art production process, covering business knowledge and behavior of 
digital art industry such as operation and management. Therefore, they are highly consistent from the origin, and they can be fully integrated.

\section{Innovation and entrepreneurship education has the same goal as digital art education}

In terms of cultivating goals, both of them require that education can improve students' innovative consciousness and creative ability, cultivate talents who meet the development of society, and establish students' future employment development direction through the practice platform, driving industry development and increasing employment rate. Therefore, the training goal of innovation and entrepreneurship education is consistent with that of digital art professional education.

\subsection{Training objectives of innovation and entrepreneurship education}

In order to make the students have the necessary knowledge, qualities and abilities for the practice of innovation and entrepreneurship, and finally become innovative talents with high quality, it is necessary to change the original teacher-based teaching model into the teaching model led by both teachers and students, starting moving towards competency-based education and carrying out innovation and entrepreneurship education.

\subsection{Training objectives of digital art education}

The purpose of digital art professional education is to cultivate innovative applied talents with the good humanistic quality, solid theoretical knowledge, superb practical skills of digital art specialty, and with the basic quality of entrepreneurship, good thinking and dare to practice. Based on learning theoretical knowledge, innovative application-oriented talents can be cultivated to be familiar with two-dimensional, three-dimensional and video editing software and to have capabilities of film and television digital art design, game design, virtual reality technology, interactive multimedia design, and digital art marketing and management.

The core of cultivation objectives of digital art education in Liaoning Shihua University is to improve students' practical and entrepreneurial employment ability, based on serving the Liaoning Manchu cultural industry, with petrochemical as the main direction. The educational philosophy of "organic combination of art and technology" is adhered, and innovative and applied undergraduate education is developed. Based on digital art professional education, the cultivation integrates innovation and entrepreneurship concept, optimize curriculum system and pay attention to practical experience; take "studio" as the platform, improve students' enthusiasm for innovation and entrepreneurship, and advocate students' innovation and entrepreneurship.

\section{The cultivation process of innovation and entrepreneurship education is consistent with that of digital art education}

In order to enable students to develop towards the direction of innovation and entrepreneurship, it is necessary for schools to create some favorable conditions, such as setting up theoretical courses of innovation and entrepreneurship education, providing a practical platform for innovation and entrepreneurship, carrying out the reform of curriculum system oriented by innovation and entrepreneurship, and promoting the cultivation of innovative and applied professionals. The digital art specialty adopts the studio training mode to realize the cultivation of professional and innovative digital art talents, with the curriculum system setting and the practice platform construction as the support. The cultivation process of innovation and entrepreneurship education is consistent with that of digital art education, and they can be integrated with each other.

\subsection{Training Process of Innovation and Entrepreneurship Education}

The cultivation of innovation and entrepreneurship requires the combination of theory and practice, using the theoretical knowledge to conduct systematic cognition, laying the foundation for the following practice, and then verifying the degree of mastery of theoretical knowledge with the combination of corresponding practical activities. They complement each other and together form a scientific way of cultivation.

\subsubsection{Theory course is the foundation of innovation and entrepreneurship education}

The theory course study of innovation and entrepreneurship education is the primary task of realizing innovation and entrepreneurship education. In the theory study, students have a basic grasp of the theoretical knowledge of innovation and entrepreneurship and have a sense of innovation and entrepreneurship. Secondly, schools should add innovative public elective courses, optimizing the teaching conditions, and incorporate the necessary courses into the curriculum, such as Entrepreneurial Foundation, Innovative Thinking and Research Methods, Career Development and Employment Guidance and other courses, laying a solid foundation for students to innovate and start a business.

\subsubsection{Building a Practice Platform for Innovation and Entrepreneurship Education}

As the platform, the studio guides the students to carry out practical training, combining theory with practice, takes the cultivation of innovative talents as the work goal, and cultivates the practical ability of college students. Through practice, students' professional quality 
and innovation ability can be improved, their spirit of innovation can be stimulated, the studio practice results can be extended, and more energy can be focused on this, being of fine workmanship, to achieve the goal of innovation and entrepreneurship.

\subsection{Training Process of Digital art Professional Education}

In terms of digital art education, in order to help graduates gain the ability to innovate and start a business, the training mode should be firstly reformed, and their four years of study should be planned reasonably; secondly, the scientific curriculum system is the criterion of all teaching behavior, and the system should include not only digital art professional knowledge, but also the knowledge in the field of innovation; finally, it is critical to build a practical platform for students to test the results.

\subsubsection{Digital art Professional Education adopts "2+2" Training model}

Digital art specialty in Lining Shihua University adopts "four-year system, two-segment" namely "2+2" professional direction of the studio of innovative and applied talent training model: in the first year, students carry out the study of the art foundation and digital art professional basic courses; in the second year, students learn the professional knowledge of digital art specialty and conduct practice; in the third year after the mutual choice of students and teachers, students study in the studio with the professional direction, according to the specific arrangements of the studio. For example, after entering the digital media art studio, students should first be familiar with and master two-dimensional, three-dimensional and film and television editing software operation ability, and the natural science knowledge of humanities, petrochemical, etc. Secondly, creative techniques required for some projects should be specifically learned according to the specific project. In the fourth year, students carry out the comprehensive practice, graduation design and other ability training.

\subsubsection{The curriculum system of combining theory and practice supports digital art education}

The construction of curriculum system is divided into theoretical course, skill course and practical course, which support each other and are indispensable. Only the reasonable curriculum system can train qualified innovative and entrepreneurial talents.

In the first semester of freshman year in Liaoning
Shihua University, the basic courses are set up, such as sketch course, color course and so on, to cultivate the establishment of students' basic digital art project design consciousness and to practice painting skills of animation characters and the scene design; in the second semester, freshmen begin to have the professional skill course, like Software Foundation. In the second year, sophomores begin their early learning of animation, setting up courses such as Animation Script Writing, Animation Character Design, Camera and Photography Foundation, etc. These courses enable students to have early creative ability; in the second semester of sophomores, Three-dimensional Digital Software, Digital Sound Effect Production and other courses are set up, which enables students to have the ability of digital art production, so that students can meet the needs of film and television production of enterprise projects, and link up well with the previous courses; juniors begin the targeted learning of digital media art direction in the studio, setting up Digital Restoration Technology, Computer Animation, Digital Media Interactive Design and other courses as the support. Combined with practical research projects and subject series curriculum system, the support relationship between the courses is strengthened, so that students can have the ability to create digital art (figure 3, figure 4). Attention is payed to the guidance of entrepreneurship education in studio teaching, promoting students' innovation, building entrepreneurial teams and incubating enterprises. The "studio" practice teaching platform is advanced, focusing on the actual combat ability and deeply practice entrepreneurship. Student's innovation and entrepreneurship can be trained through projects and competition. Unifying the theory education, the instruction of the practice process for students should be strengthened. In addition, based on the advantages of colleges and universities, Lining Shihua University creates a better condition of employment and entrepreneurship for students. Lining Shihua University adds relevant courses, combining digital art professional education with petrochemical process. Digital art specialty has launched the petrochemical digital art characteristic courses: Introduction to Petrochemical Industry B, Chemical Virtual Reality Demonstration Animation of Process and Equipment, Mechanical Structure and Principle Demonstration Animation, emphasizing that based on the digital art design students can highlight the characteristic of digital art design in the petrochemical field (figure 5) and realize the multiple cross of digital art specialty. The combination of digital art and other industries meets the requirement of the era. 


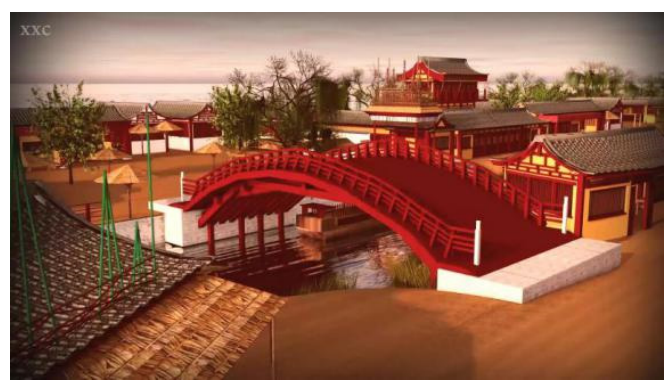

Figure 3. Digital restoration technology in Riverside Scene at Qingming Festival.

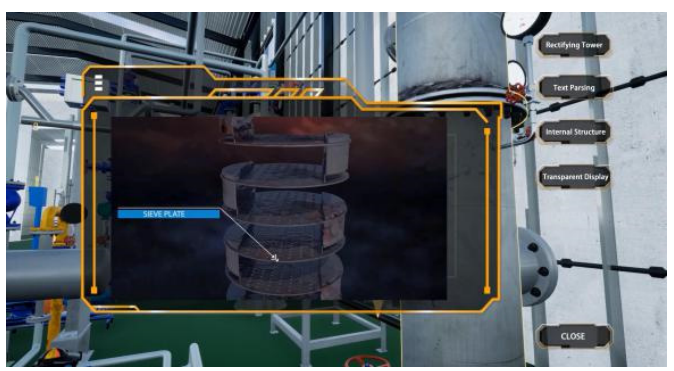

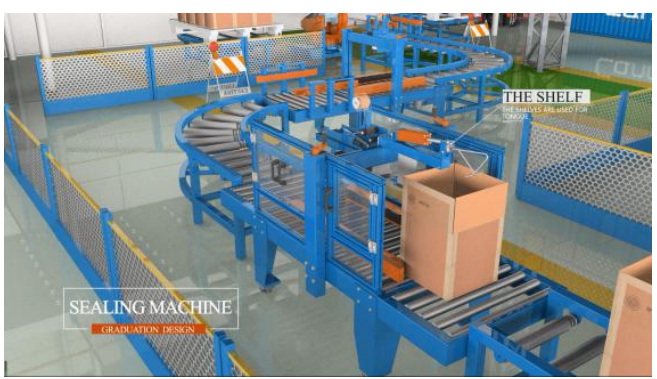

Figure 4. Digital simulation of packaging production line.

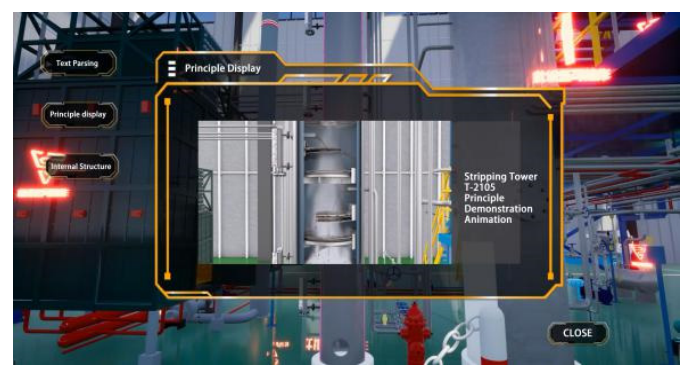

Figure 5. Virtual teaching platform of technological process equipment-- rectifying tower and stripping tower.

These courses not only enable students to master solid theoretical knowledge, but also deepen and enrich art and design practice, providing important knowledge background as a support and multiple creative perspectives.

\subsubsection{Strengthen the digital art professional education by building a practice platform}

After studying all the courses arranged by the college, the students need to prove themselves through the practical contact with the industry, and the college also needs to test the teaching results by entering the industry, so it requires the college, as a bridge between the students and the society, to build the practice platform of innovation and entrepreneurship for the students, meeting the needs of the students and the society.

Establishing a practical platform in the college provides practical opportunities for students, such as the establishment of the practice base of innovation and entrepreneurship, community practice base, setting up digital art production laboratory, holding the practice competition of innovation and entrepreneurship, and integrating practical research projects and topics into teaching (figure 6). The construction of practical platform in college is helpful for students to explore the road of innovation and entrepreneurship, and to understand innovation and entrepreneurship deeply. Competitions can highlight a group of outstanding talents with innovative and entrepreneurial capabilities, and the focus on the training of the talents can promote the inheritance and development of innovative spirit of college students.

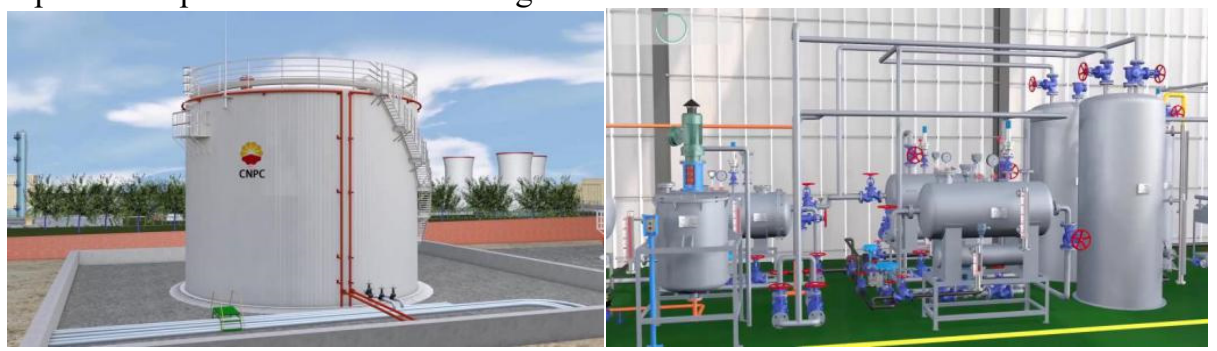

Figure 6. Petrochemical visual simulation training system.

\section{The Effective Way of Integrating Innovation and Entrepreneurship Education into the education of Digital Art Specialty}

It is an effective way of implementing the training mode of "professional orientation studio" to integrate innovation and entrepreneurship education into the education of digital art specialty. The training model of "professional orientation studio" applies the studio to simulate the working environment, helping students contact with realistic digital art production situation to complete the theoretical learning and the practical operation. Training in the actual project from the actual production position, the teaching model of " integrated production-learning-research " is implemented, 
integrating the studio into the classroom. At the same time, strengthening targeted guidance is the goal of the implementation of innovation and entrepreneurship, and a reliable measure to cultivate innovative digital art talents.

\subsection{Advantages of " Professional Orientation Studio "Mode}

The practical teaching platform of "professional orientation studio" can provide students with a real

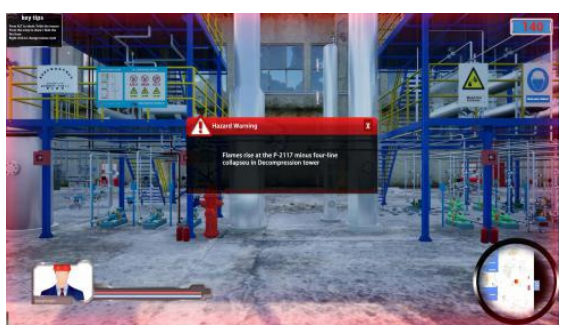

teaching platform of the enterprise practical environment, and realize the interrelation between theory and practice, and between teaching and market (figure 7). Through the teaching platform, students can really know the real operation mode of the enterprise, improve the students' practical ability and enhance the students' innovative spirit. Therefore, students can understand the real needs of the industry enterprises, and then establish their own future development direction, achieving the goal of cultivating innovative professionals.

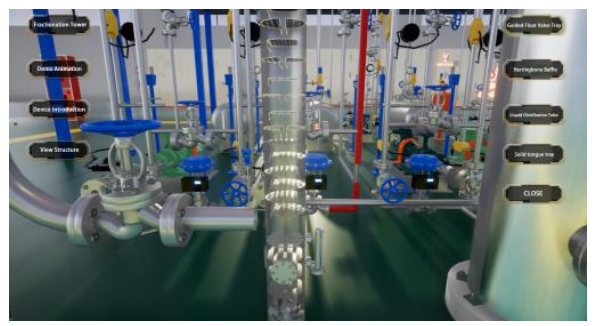

Figure 7. Petrochemical visual training system.

\subsection{Operation Mechanism of "Professional Orientation Studio"}

Digital art studio operates according to the management mode of the regular company, and studio positions are divided into professional teachers and student leaders. Professional teachers are responsible for the connection between the project and the enterprise and the launching of innovation projects. According to the advantages, interests and hobbies, students are divided into several groups. The projects are assigned to each group, and the team leader assigns the task to each group member. Team members discuss together and complete the project. After the completion of the project, the group reports verification as a unit to ensure that the project is highly regularized. In the innovation project, the studio members discuss their own ideas and views together, which can fully stimulate everyone's enthusiasm for innovation.

Project-led students as the main body. For the project, students set up a teacher-led gradient management model to complete the project as the main purpose. The teacher assigns tasks to each team leader, and the team leader assigns tasks to each team member producing the project effectively. The course and the project practice are integrated, and the project production and teaching are combined. Students get the overall improvement of the comprehensive ability through the completion of the actual project.

For competitions, teachers provide students with sufficient creative points or competition information, stimulating students' innovative ability and assisting students to complete the production of innovative projects or competitions (figure 8). By focusing on and cultivating professional skills and abilities, the natural integration of digital art specialty into innovation and entrepreneurship is promoted, so that students can gain stronger operational skills, richer professional knowledge and more unique innovative ability and the production can have stronger practical value.

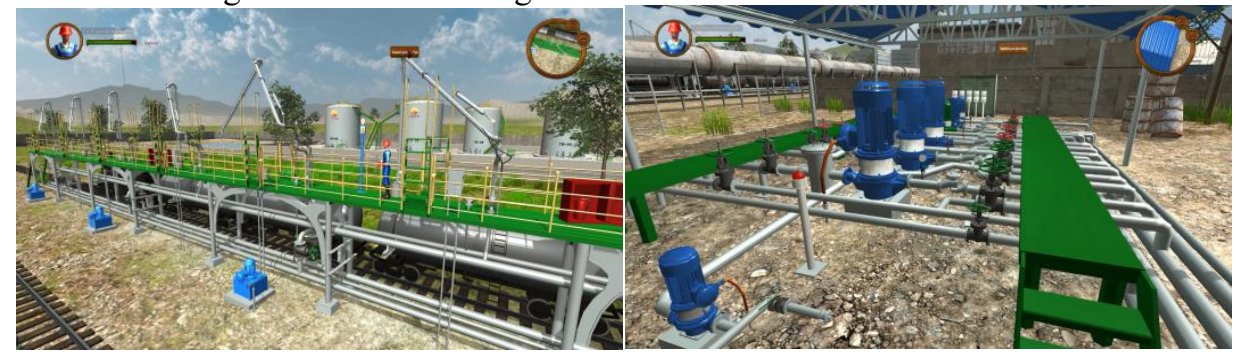

Figure 8. Interactive design of petrochemical virtual evaluation system

\section{Effectively Solving the Key Problems Existing in Digital Art Industry}

The training mode of digital art specialty combining innovation and entrepreneurship education solves the key problems in digital art industry. Innovation and entrepreneurship education provides a new scheme to solve the employment problem for college graduates and plays a positive role in the development of social economy. Under the restriction of the traditional education idea for many years, innovation and entrepreneurship education of digital art specialty in colleges and universities still has great deficiency. The digital art professional training model integrating innovation and entrepreneurship education solves the 
main problems existing in digital art students, digital art professional education in colleges and universities, industry, society, etc.

\subsection{Solving the problems of students' self-development and self-worth realization}

The model integrating innovation and entrepreneurship education into digital art professional training helps students accumulate the rich professional knowledge, understand the knowledge of innovation and entrepreneurship, psychology and other related majors, promoting students to master comprehensive knowledge modules, improving the knowledge structure, and enabling students to use the theory of mastery to solve the problems in practice.

The cultivation of creative and entrepreneurial talents of digital art specialty in Lining Shihua University adopts a new educational idea with the equal emphasis on theory and practice. By participating in practical projects or other practical activities of innovation and entrepreneurship, students can produce self-awareness and innovative consciousness, arousing their interest in innovation and entrepreneurship, strengthening students' initiative in innovation and entrepreneurship, being conducive to the development of innovation and entrepreneurship activities, and improving students' practical ability.

\subsection{Solving the problem of digital art professional education development}

The model integrating innovation and entrepreneurship education into digital art professional training promotes the active participation of industry enterprises. Colleges, industry, and enterprises work together towards the road of cooperation between schools and enterprises. The combination of innovation and entrepreneurship and digital art specialty education is beneficial to the talent training, makes the main body of digital art specialty rich, and improves the teaching quality and the employment rate of digital art specialty in colleges and universities.

\subsection{Solving the problem of industry and socio-economic development}

The innovation and entrepreneurship education of digital art specialty pays attention to the market demand. Through the deep analysis of the educational goal, the curriculum system is accurately set up, injecting the fresh blood of innovation and entrepreneurship into the digital art industry and society. Innovative practice teaching relates to the actual project of the enterprise, so that the college and the enterprise are effectively integrated, enhancing the student employment rate obviously, providing more employment positions for the society, and satisfying the actual demand of the social economic progress.

To sum up, in the new era, the world has focused on innovation, and it has undoubtedly become a new favorite in the trend of the times. As an emerging major in the current national higher education, digital art specialty has the inherent innovation, and this coincides with the national requirements for higher education in the new era, so the model integrating innovation and entrepreneurship education into digital art professional training comes into being. The new training mode promotes the overall progress of national talent training and enhances the national comprehensive strength by improving the quality of school running. The innovation and entrepreneurship education of digital art specialty under the studio mode encourages students to innovate first and then start a business, and it requires students to initially have the innovation ability to conform to the trend of the times and to meet the requirements of the industry. It can contribute to the development of the industry through the improvement of innovation ability. Innovation is the premise and the soul of entrepreneurship, and the high-level innovation ability and the working experience lay a solid foundation for entrepreneurship. Innovation and entrepreneurship provides the driving force for the sustainable development of the industry and the professional level, effectively stimulating the development of social economy and meeting the employment requirements of students in this major at the same time. Under the effective operation of this new training mode, the students' passion for innovation and entrepreneurship is fully mobilized, which infuses fresh blood into the development of the industry, giving a new plan for the socio-economic development and providing a strong guarantee for the improvement of the country's position on the stage of the global comprehensive national strength competition.

In the context of new media, digital art formed by the harmonious combination of emerging digital technology and visual art has brought real value and impact to many areas of human life. The digital form can change the professional boundaries from dividing lines to network crossing. Facing unintelligible cross-disciplinary theories, the cross-industry application of digital art breaks the boundary between technology and art, combining digital art with products and using technological means and artistic images to interpret information. It makes that digital art professionals are not limited to pure art creation and can also keep pace with the times, which maximizes the self-worth of digital art professionals and has far-reaching significance for the cultivation of the comprehensive ability.

\section{About the authors}

Wenbin Ge (1984-), male, from Shenyang, Liaoning province, Master's degree, lecturer of Liaoning Shihua University, research direction: visual interactive design; Lin Gao (1995-), female, from Wenshui, Shanxi province, Master degree candidate, Liaoning Shihua University, research direction: digital design.

\section{Acknowledgments}

Fund project: This thesis is a phased research result of 
construction project of "innovation and entrepreneurship reform pilot major -- animation" in "Quality Improvement Project" in Liaoning province". (Approval document: Letter from the Educational Department of Liaoning Province [2018] no. 394)

\section{References}

1. Tang, L.J. (2014) Analysis of the practical significance and effective ways of life education for college nursing students. Nursing Research, Early Edition:769-770.

2. Wu, Y. (2016) A Study on the Mode of Entrepreneurship Education for College Students in Shanxi Province under the Background of Internet. Chizi, Early Middle Edition:76.

3. Zou, J.H. (2012) Liaoyuan City: Full Implementation of the "Eight Major Projects" for Entrepreneurship and Employment. Labor security world:13.

4. Li, J. (2013) Research on the Construction of Art Design Specialty in Independent College. Art Education Research: 68.

5. Tan, L.Y. (2014) Analysis on the Problems and Countermeasures of Entrepreneurial Talent Training in Private Universities. Modern Enterprise Education: 90.

6. CNKI.(2019). The Academic Trends of New Media Animation. http://trend.cnki.net/TrendSearch/trendshow. htm?searchword=\%u65B $\%$ u 5 A $92 \%$ u 4 F $53 \%$ u 52 A 8 \%u753B.html,2019-10.

7. Xia, Y. C., Li, J.(2019). A Probe into the Creative Training Mode in Advertising Animation Teaching. Decoration,2009(10):96 97.

8. Xia, Y. C.(2011). Functional Animation Development and Education Research. Decoration,2011(02):129 130.

9. Wang, L. X.(2018). The Influence of Animation Symbols on New Media: a Reflection on the Theory of "Hot and Cold Media". Modern Communication (Journal of Communication University of China),2018,40(01):123 127.

10. Li, L.F.(2009).Research on Oil and Gas Wellbore Data Visualization System. Inner Mongolia Petrochemical Industry. 2009 (07) : 24-25

11. Vin Crosbie. (2015).What is "New Media"[EB/OL].http//:rebuilding-media.Corante.co m.

12. Chen, R.R.(2017).Media Evolution and Art Communication. China International Radio Press, Beijing.

13. Guo, Y. C., Gu, X. J., Shi, L.(2015).Virtual Reality and Interaction Design. Wuhan University Press, Wuhan.

14. Zhang, T.T., Tian, F., Lv, W. (2017). Overview of the Application of VR in the Field of Interactive Film and Game. Journal of Shanghai University (Natural
Science Edition), 23(3):342 352.

15. Xu, T.(2016).Theoretical Exploration on New Media Animation-Comment on Introduction to New Media Animation. Youth Journalist, 2016(32):102.

16. Li, M. Liu, D. B., Zhang, H.(2016). Research on the audience of Chinese animation. Chinese Book Company. Beijing.

17. Feng, J.W., Zhang, X., Hu, C. L.(2019). Technical Analysis of VR Panoramic Film and Television. Wireless Interconnection Technology,16(11):135 $\sim 136$.

18. Wang, J.Q.(2017). The Rise and Development of China's New Media Animation from the Perspective of IP Appreciation. China Television,2017(06):45 48.

19. Yi, T., Li, Y.Y., Su, Y.(2009). Disaster Accident Simulation System Based on Virtual Reality Technology. Computers and Applied Chemistry, 2009, 26(8):966-970. 